\title{
AN ESTIMATION OF THE COMPLIANCE COSTS OF SLOVAK TAXATION
}

\author{
Juraj Nemec, Pavol Čižmárik, Vladimír Šagát
}

\section{Introduction}

The first integrated concept of taxation expenses was presented by Smith (2005), whose Canons of Taxation formed the starting point for the study of the theory and practice of taxation. Equity, certainty, convenience and efficiency represent the principles that inform the development of contemporary taxation theory and influence the development of opinion on the additional expenses of taxation, both in the public and private sectors, which will be the main object of our interest. What is most significantly connected to our theme is the efficiency of taxation, which appears to be a chronic problem, and hence has been the focus of both theoretical and empirical work in recent decades. The productivity of tax officials and the compliance costs of taxpayers have been the focus of researchers for many years in all developed countries.

In contrast to the situation in older developed countries, the only studies of the administrative and compliance costs of taxation in Central and Eastern Europe are for Croatia, Slovenia, the Czech Republic and recently for Slovakia. Our goal in this paper is to add more about Slovakia to the list. Slovakia is a member of the European Union, of its EURO-zone, and a medium income OECD member. This paper focuses on the compliance costs of taxation with the goal to assess the level of compliance costs of the private sector for income taxation and compliance costs for employers connected with the administration of salaries and social contributions.

\section{Existing Research and Approaches}

The costs of taxation are analyzed in one of two ways. A first group of authors refers only to the expenses of the public sector. Sandford, Godwin and Hardwick (1989) describe the "administrative costs of taxation" as a subset of the public sector's expenses, in which he also includes so-called other or sundry costs. A second group of authors divide the costs of taxation into two subsets. The first subset "direct administrative costs" are the direct costs of the public sector. The second subset the "compliance costs of taxation" are the indirect expenses of the private sector. Our understanding of the term "costs of taxation" is set out in Fig. 1 and will be used in the analytical part.

Investigations into the costs of taxation, which began before the Second World War (for example Haig (1935)), grew rapidly in the 1950's and 1960's (Oster \& Lynn, 1955; Matthews, 1957; Bryden, 1961; Johnston, 1963) and peaked with seminal works by Sandford and his group (1989; 1995), Slemrod and Sorum (1984) and Vaillancourt (1987). These latter researches, focusing mainly on methodological and conceptual problems, created the basis for current research on the topic.

For more recent articles, because of the empirical focus of this paper, we highlight only European research: for a very detailed wider overview see Evans (2003). Within Europe Allers (1995) covered the Netherlands, Sweden was dealt with by Malmer (1995), Hasseldine and Hansford (2002) analysed Value Added Tax problems in the UK, including increased expenses in companies with higher turnover, and the increasing complexity of the tax system. Blaufus, Eichfelder, and Hundsdoerfer (2014) published results for Germany on an analysis of time requirements, the incomes of individuals and society, and the use of external services, and Díaz and Delgado (1995) investigated the Spanish situation.

Compared to Western Europe, the number of studies directly focusing on the costs of taxation in Central and Eastern Europe is rather 


\section{Ekonomie}

\section{Fig. 1: Costs of taxation}

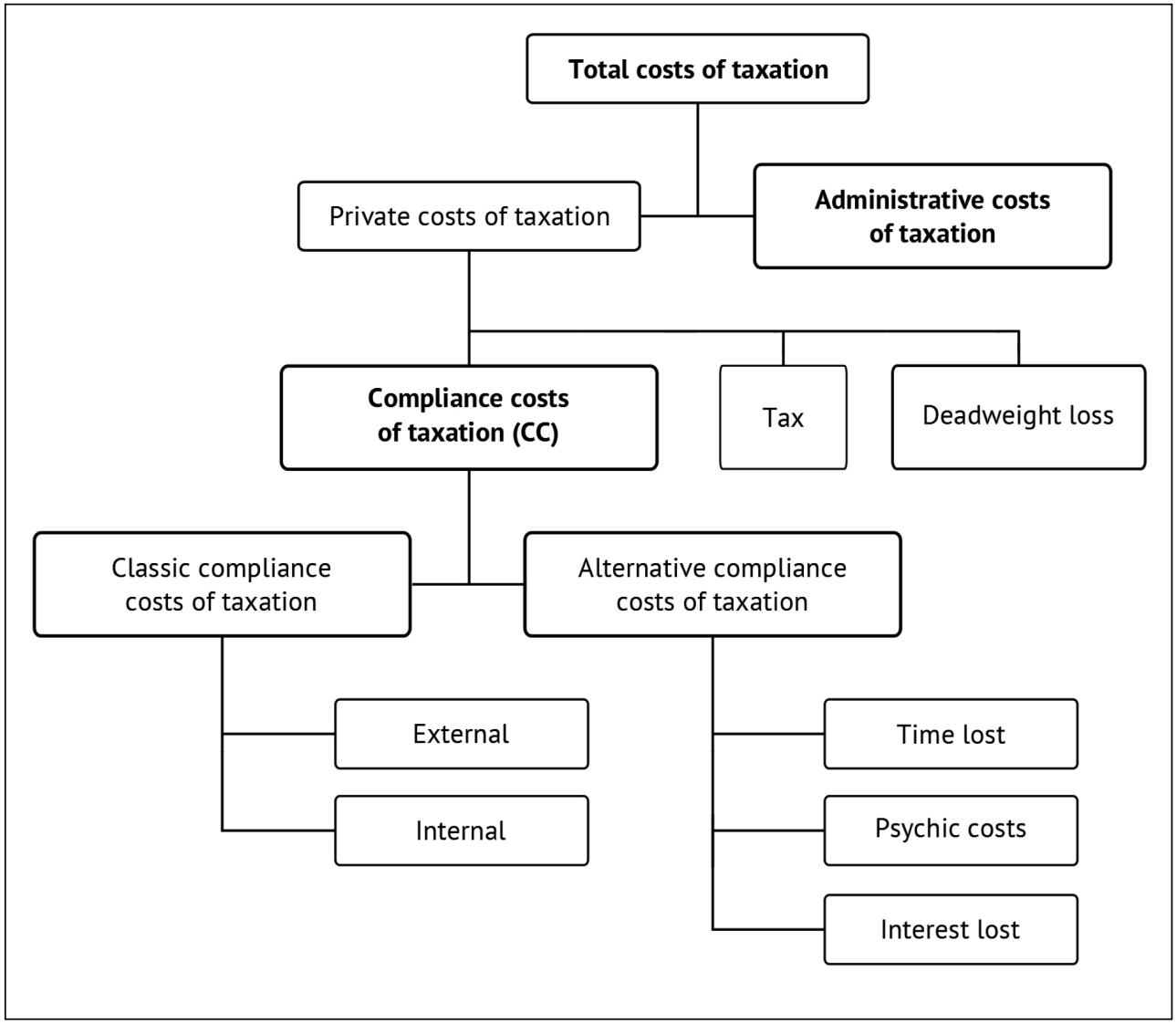

Source: processed from quoted sources by authors

limited. We are able to mention only Klun (2001; 2003; 2004; 2009) who analyzed the situation in Slovenia, Blažič (2004a; 2004b) who focused on income taxation in Croatia (plus their comparative study in 2005) and especially the "Czech school", headed by Vitek (see e.g. Vitková and Vitek (2002); Vitek, Pavel, and Pubal (2002); Pudil, Vybíhal, Vítek, and Pavel, (2004); Vítek, Pavel, and Krbová (2004); Vítek and Pavel (2008); Vítek (2008); Jílkova, Pavel, and Slavíková (2009); Pavel and Vítek (2015)).

For Slovakia, Orviska and Hudson (2003) should be noted, although they only deal with the topic indirectly, from the viewpoint of tax evasion, and recently our team published estimates for the administrative costs of taxation (Nemec, Pompura, \& Šagát, 2015), using the Czech approach of Vitek (2008), who assumes that the total costs of tax offices can be used to deduce the administrative costs of taxation by weighting, where the weight is the proportion of tax office employees involved in tax collection - Tab. 1. The results of this study are not very positive, because (similarly to the OECD studies) they indicate that the tax administration in Slovakia is very expensive. Other indirect resources from the Czech Republic and Slovakia are for example Matějka (2009), Hruška and Dvořáková (2013) or Hájek, Hamplová, Jedlička, and Kovárník (2013). 
Administrative costs of taxation in Slovakia as a percentage of tax revenues, by specified tax, 2004-2011

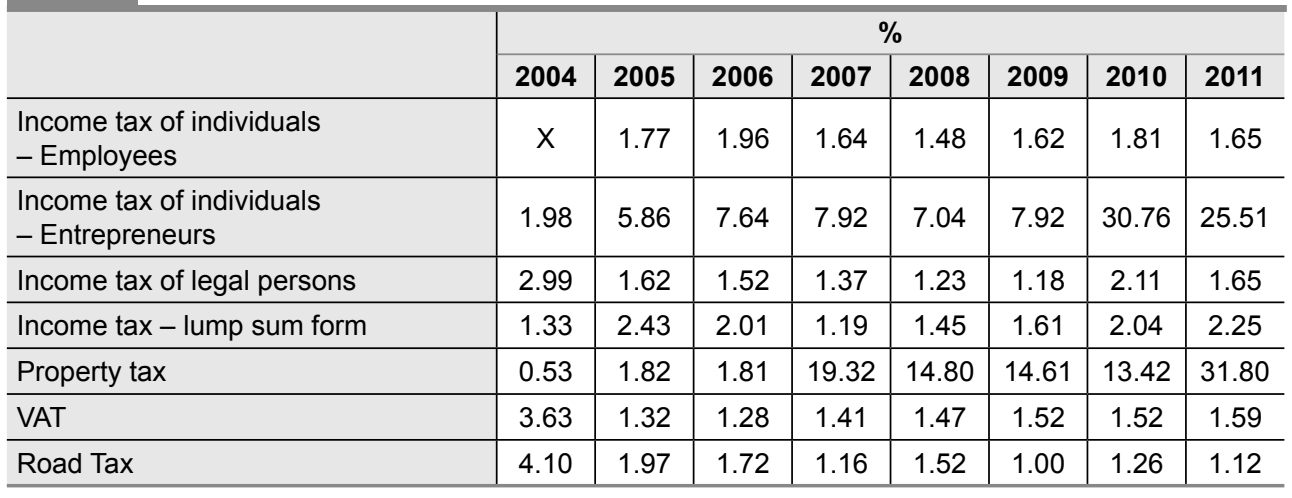

Source: Nemec, Pompura and Šagát (2015)

\section{Estimating Compliance Costs of Income Taxation}

In this part we describe the research methodology (process and main assumptions and simplifications) and provide and discuss our findings.

\subsection{Methodological Issues}

To obtain the necessary data needed for estimating the compliance costs of taxation we used a questionnaire (see annex for a simplified version), distributed by electronic post and accessible also on line. With the goal to collect as precise data as possible, the research was undertaken in two phases - the pilot phase and the main phase. The goal of the pilot phase was to test the methodology, especially the structure and the contents of the questionnaire and also to popularize the issue, to attract tax payers to participate in the main phase.

A series of articles was published by the authors using the blog section of the weekly economic journal Trend to spread the information about the topic and the planned research in early 2012 . The pilot phase started on 2012-02-21 and ended on 2012-04-24. During this period we received 110 responses. All respondents from this phase were directly invited to participate in the main phase. The purpose for such approach (limiting the representativeness of the sample) is simple there is no the publicly available list of taxpayers registered for income taxes in Slovakia. In such a situation the standard statistical random selection of the sample was impossible. Our sample was self-selecting.

The total sample achieved was 88 responses, from which we had to exclude eight respondents for formal reasons. The structure of the remaining 80 respondents is described by the Tab. 2 - where it is also compared with the situation in the national economy. The statistical significance of the sample was tested by a Pearson test with a $5 \%$ significance level and the achieved $p$-value was 0.844 for physical persons and 0.094 for legal persons as a group - this should mean that the sample has statistical relevance.

From the point of view of other factors that are important when estimating compliance costs (see for example Collard and Godwin (1999)) we provide information about the size that really impacts the percentage of compliance costs in all existing studies. Concerning the size, measured by the turnover, fourteen respondents refused to provide data. Amongst the rest, smaller businesses with an annual turnover below 25,000 EUR dominate $(40 \%)-$ Tab. 3. This information cannot be exactly compared with the situation (structure of businesses) in the national economy, because the necessary national data are not available. However, according to existing estimates, the sample seems to be reasonably representative and we expect that the average calculations are not biased by the dominance of one specific size group of businesses. 


\begin{tabular}{c|c|c}
\multicolumn{1}{c|}{ Category } & Our sample & $\begin{array}{c}\text { Total } \\
\text { in economy }\end{array}$ \\
\hline Self-employed (from total number of entrepreneurs - physical persons) & $85.37 \%$ & $86.42 \%$ \\
\hline Other legal forms (from total number of entrepreneurs - physical persons) & $14.63 \%$ & $13.58 \%$ \\
\hline
\end{tabular}

Percentage of entrepreneurs - physical persons (individuals) in Slovakia covered by our research: $0.01 \%$

\begin{tabular}{l|c|c}
\hline Limited companies (from total number of legal persons) & $87.18 \%$ & $93.70 \%$ \\
\hline Shareholder companies (from total number of legal persons) & $2.56 \%$ & $3.88 \%$ \\
\hline Other legal forms (from total number of legal persons) & $10.26 \%$ & $2.42 \%$ \\
\hline
\end{tabular}

Percentage of legal persons (firms) in Slovakia covered by our research: $0.02 \%$

\section{Tab. 3: Size of respondents (annual turnover)}

\begin{tabular}{l|c}
\multicolumn{1}{c|}{ Annual turnover } & Percentage from the sample \\
\hline Below 25,000 EUR & $40 \%$ \\
\hline $25,000-100,000$ EUR & $23 \%$ \\
\hline $100,000-1,000,000$ EUR & $16 \%$ \\
\hline Over $1,000,000$ EUR & $8 \%$ \\
\hline Did not respond & $13 \%$ \\
\hline
\end{tabular}

As Fig. 1 indicates, compliance costs of taxation occur in different forms and we tried to include not only classic compliance costs that occurred internally, or were paid to external bodies, but also some indirect compliance costs - namely the value of time (see Sandford (1989, pp. 35-39)). We decided to value time at $200 \%$ of the average wage - that is $9 \mathrm{EUR} /$ hour. In other words we assume that the hourly value of businesses' time is twice that of the average employee.

We did not include psychic costs because of too many difficulties. We also did not try to calculate any potential monetary and nonmonetary benefits connected with paying taxes (like interest costs differences - concerning this issue we assumed that any interest rate losses were compensated by gains).

Another methodological issue was the estimate of the proportion of the hardware costs. In cases where the respondent did not provide concrete data about hardware costs used in connection with tax payments, we assumed lump sum annual costs of 200 EUR.

It was important to estimate the accounting costs to be appropriated to the total compliance costs. The Coefficient " $A$ " is used to estimate what part of total accounting related costs can be allocated to the compliance costs of taxation. Coefficient " $A$ " has different values, depending on answers by respondents to the question "Why do you maintain your accounting system", as follows:

$A=1$ for the response: "Only because this is legal obligation, if this were not required by law I would not have it".

$A=0.6$ for the response: "The main reason is the legal obligation, but I use some information from the accounting system to manage my business".

$A=0.3$ for the response: "Accounting is an unavoidable source of management information for us".

The fact that we directly interviewed respondents to help us allocate an appropriate 
part of the costs of their accounting system to compliance costs should provide better results compared to many other existing estimates, for example those made by the type of company (see Vitek (2008)).

The final issue was to estimate what proportion of the total compliance cost should be connected with income taxation duties. Coefficient " $B$ " is used to allocate total compliance costs between two taxes that fall within our research - income tax and value added tax. These are the dominant taxes, by revenue raised, so we ignore other small taxes. Coefficient "B" also has different values, depending on respondents' answers to the question "What is your estimate of VAT costs in total compliance costs", as follows:

$\mathrm{B}=1$ for the response: "I do not pay VAT".

$B=0.75$ for the response: "Less than $25 \%$ ".

$\mathrm{B}=0.5$ for the response: "About $50 \%$ ".

$\mathrm{B}=0.25$ for the response: "More than $75 \%$ ".

\subsection{Results and Discussion}

The estimated compliance costs of the income taxation in Slovakia are presented in the Tab. 4 and discussed by the following text.

\section{Tab. 4: Estimated costs of taxation in Slovakia in 2011: income taxation}

\begin{tabular}{|c|c|c|c|c|c|c|}
\hline $\begin{array}{l}\text { Subject: } \\
\text { Legal form }\end{array}$ & $\begin{array}{l}\text { Average CC } \\
\text { (EUR) }\end{array}$ & $\begin{array}{c}\text { Total number } \\
\text { of tax } \\
\text { subjects }\end{array}$ & $\begin{array}{l}\text { Total CC } \\
\text { (EUR) }\end{array}$ & $\begin{array}{l}\text { Total tax reve- } \\
\text { nues (EUR) }\end{array}$ & $\begin{array}{c}\text { Relative CC } \\
\text { (\%) }\end{array}$ & $\begin{array}{c}\text { CC to GDP } \\
(\%)\end{array}$ \\
\hline Self-employed & 861 & 481,996 & $414,871,309$ & $x$ & $x$ & $x$ \\
\hline Other physical persons & 770 & 75,754 & $58,354,569$ & $x$ & $x$ & $x$ \\
\hline \multicolumn{3}{|l|}{ Physical persons total } & $473,225,878$ & $56,402,000$ & $839.02 \%$ & $0.69 \%$ \\
\hline Limited companies & 4,067 & 181,192 & $736,921,800$ & $x$ & $x$ & $x$ \\
\hline Other companies & 3,186 & 12,191 & $38,841,609$ & $x$ & $x$ & $x$ \\
\hline \multicolumn{3}{|l|}{ Legal persons total } & $775,763,409$ & $1,645,905,000$ & $47.13 \%$ & $1.12 \%$ \\
\hline \multicolumn{3}{|l|}{ Total } & $1,248,989,287$ & $1,702,307,000$ & $73.37 \%$ & $1.81 \%$ \\
\hline
\end{tabular}

Our findings, especially the estimates of compliance costs for income taxation of physical persons, are very negative and this fact provides the impetus for a comprehensive discussion. To demonstrate the possible impacts of several important factors on our results, we recalculated the results for the following possible biases - the total tax revenues from income tax, the real total number of legal persons, replacing average with median data, different values of the coefficient " $A$ " and different monetary values of time.

Without any doubt, the total income tax revenues play an important role because of the crisis. According to the data of the Ministry of Finance, the 2011 revenues from income tax of physical persons were $71.12 \%$ lower compared to pre-crisis situation. For legal persons the decrease was $23.67 \%$. So the crisis meant that the year we chose was atypical and the importance of compliance costs was thereby exaggerated. The recalculated results for this factor are shown as alternative A in Tab. 5.

Another clear bias is connected with the official data about the number of tax payers. The registry includes both physical and legal persons who are not active. We estimate that this group represents about $15 \%$ of the total numbers given. Reducing the total numbers in this way generates alternative B in Tab. 5 .

The relatively small, though representative sample may be better characterized by median rather than average data. Replacing average with median data generates alternative $C$ in Tab. 5.

To demonstrate the role of the coefficient "A" which allows us to estimate the share of compliance costs in total accounting related costs we recalculated the results with different percentages (90, 50 and 20 instead of 100, 60 and 30) - leading to alternative D in Tab. 5.

All authors dealing with the topic had to decide how to covert time data to financial values. This aspect is really important - for 


\begin{tabular}{l|c|c|c}
\multicolumn{1}{c|}{ Alternative } & $\begin{array}{c}\text { CC to tax revenues } \\
\text { total }\end{array}$ & $\begin{array}{c}\text { CC to tax revenues } \\
\text { physical persons }\end{array}$ & $\begin{array}{c}\text { CC to tax revenues } \\
\text { legal persons }\end{array}$ \\
\hline Original results & $73.37 \%$ & $839.02 \%$ & $47.13 \%$ \\
\hline Alternative „A“ & $53.11 \%$ & $242.29 \%$ & $35.98 \%$ \\
\hline Alternative „B" & $62.36 \%$ & $713.17 \%$ & $40.06 \%$ \\
\hline Alternative „C" & $40.12 \%$ & $637.04 \%$ & $19.67 \%$ \\
\hline Alternative „D“ & $61.36 \%$ & $734.61 \%$ & $38.29 \%$ \\
\hline Alternative „E" & $62.99 \%$ & $599.71 \%$ & $44.59 \%$ \\
\hline Alternative „A+B+C" & $24.69 \%$ & $156.37 \%$ & $12.76 \%$ \\
\hline
\end{tabular}

example Vaillancourt (1986), Klun (2003) and Blažič $(2004 a, b)$ decided to use the average wage. The recalculation of our results using the average wage generates alternative $\mathrm{E}$ in Tab. 5 .

The most cautious calculation is generated by simultaneously applying the corrections $A, B$, and $C$ to the compliance cost calculations. This corrects for possible biases due to the crisis, an inflated number of taxpayers, and inaccuracies due to using average rather than median data. The revised calculation is alternative $A+B+C$ in Tab. 5.

Our calculations show that even if we use the most cautious assumptions, the compliance costs of taxation in Slovakia are higher compared to those in most other studies - both in our region but also beyond it. Data collected by Vitek (2008) in Czech conditions that are similar to Slovakia, are about half our levels for legal persons $(14.9 \%)$ but noncomparable for physical persons (27.8\%). Blazic (2004b) calculated the compliance costs of small businesses in Croatia as being $31.39 \%$ of income tax revenues. Vitek and Pavel (2008) report that compliance costs represent $5.5 \%$ of income tax revenues for legal persons and $35.4 \%$ for physical persons. Only Vitkova and Vítek (2002) have results that are close to our estimates. She reports $427 \%$ for physical persons and $55 \%$ for legal persons.

The comparison with developed countries is even more negative. The lowest results for existing studies begin around 5\% compliance costs to income tax revenues. For example Allers (1994) has 4\% for the Netherlands. But the highest levels are still below $20 \%$. For example Pope (1993) reports $14.5 \%$ for Australia.

\section{Estimating Compliance Costs for Employers Connected with the Administration of Salaries and Social Contributions}

For the research about employer compliance costs we only received 23 responses, and one was excluded for formal reasons. Companies represent $73 \%$ of the sample and physical persons with employees $27 \%$. This sample is not statistically representative and because of this we only briefly present the methodology and main findings.

Concerning the methodology, it was not necessary to use any coefficients, because the salary and social contribution agenda is an independent part of employers' agendas and its costs can be directly estimated. The only problematic issue was the estimate of the interest revenues gained by delays connected with the interval between deducting and paying over income tax and social contributions to the tax authorities. This should decrease compliance costs. The interest revenue is calculated as follows - monthly payments, an assumed $1 \%$ interest rate, with fifteen days delay for paying over social contributions, and twenty days delay for income tax to be paid on behalf of employees.

According to our estimates in 2011 the average costs per employer to pay income tax and social contributions for employees were 4,596 EUR. With a total 155,047 employers registered in the central registry the aggregate costs were $712,647,882$ EUR. The revenues from income tax of employees and their social contributions in Slovakia were 7,736,562,411 EUR (www.finance.gov.sk). 
Thus the compliance costs represent $9.21 \%$ of this type of state revenues, or $1.03 \%$ of GDP. The net gain via interest revenues was estimated at 3,404,255 EUR, which does not significantly reduce compliance costs.

\section{Conclusions}

The goal of this research was to estimate the compliance costs of taxation in the Slovak Republic. Unfortunately the results are rather negative - even the most cautious estimates are higher than those reported for other countries. Based on the existing research and our data we can conclude that the Slovak tax system significantly underperforms on both the administrative and compliance costs of taxation. And this is despite the fact that these two aspects of the efficiency of taxation are not directly connected, for under certain conditions the same country may have cheap tax administration but a complicated system for taxpayers to pay their taxes. The situation deserves attention and motivates a search for some explanations.

The existence of high administrative costs has already been reflected in Slovak government action: in 2012 the large scale tax system reform (UNITAS) was undertaken by the government. Its main goals are to improve the flow and use of information and to merge the collection of all taxes and social contributions under one administration.

However, there has been very limited discussion and no policy proclamations or concrete actions in the area of compliance costs in Slovakia. Moreover recent developments clearly show that the focus of government is not on simplifying the duties of taxpayers. Pursuing the official policy of increasing tax revenues the government has introduced several new measures to prevent tax evasion. But all these measures are rather costly for honest and diligent taxpayers. An example is the "control statement for VAT", employed as a tool to prevent carousel frauds. The authors do not feel that such a "one size fits all - for all taxpayers may be guilty" approach really helps, not least because extra universal compliance requirements may well lead to substantial increases in compliance costs. Such extra requirements are more efficient if focused on those taxpayers whose measureable situation raises a significant concern that they may be evading their taxes. Yet Slovakia is one of the few EU countries where taxpayers may not be required to explain how their wealth, consumption and income are related. Taxpayers with very high living standards may declare a zero taxable income without attracting official attention.

Our data indicate that two core factors determine the extremely high relative level of compliance costs - a complicated tax system and a low level of income tax revenues (if we compare compliance costs to GDP, the results are less negative, but still not satisfactory). Both are not sufficiently, if at all addressed by government action.

Concerning the low level of income tax revenues, more dimensions could be discussed. We decided to focus on tax evasion and tax system (tax revenues and tax rates). Orviska and Hudson (2003) clearly indicate that tax evasion is common approach in Slovak business, in part perhaps because the risk of punishment is low. For example Slovakia is the only EU country to apply the principle of "effective regret". Even taxpayers caught by the tax office for evasion can retrospectively pay their tax assessments, plus a $10 \%$ surcharge, and remain "clean", provided they pay up before the final court decision.

The revenues from the income taxation in Slovakia is one of the lowest in the European Union. According to the official Eurostat data Slovak income (direct) tax revenues in 2012 represented only $5.6 \%$ of GDP (one of three lowest). The fact that many countries have lower implicit tax rates for income taxation but higher income tax revenues is in line with above mentioned problem of tax evasion.

The issue of tax system complexity was partly addressed during the 2004 tax reform. This introduced a lump sum tax for small businesses, but it was abolished a few years later. Today, small businesses can use the lump sum costs method in completing their income tax forms. But the maximum level of lump sum costs is $40 \%$ of revenues, with a 5,040 euro absolute limit. This is rather discouraging and most businesses prefer to claim real costs.

One specific factor that may have had an impact on the limited will of the government to enact necessary radical changes, uncovered by our research, is tax illusion. During the research on compliance costs we asked respondents their opinion about such costs. The responses were rather surprising $-8 \%$ of respondents 
felt that compliance costs were marginal and $31 \%$ felt that their level was fully acceptable. Their views of the payroll system were not so positive, but even so $46 \%$ of respondents felt that its costs were acceptable. This situation provides one more - political - explanation for the current situation: if tax payers are not well informed their motivation to demand change is limited.

This research was supported by the Czech Science Foundation (GA CR) under project GA16-13119S "Performance management in public administration - theory vs. practices in the Czech Republic and other CEE countries".

\section{References}

Allers, M. (1994). Administrative and Compliance Costs of Taxation and Public Transfers in the Netherlands. Groningen: Wolters Noordhoff.

Blaufus, K., Eichfelder, S., \& Hundsdoerfer, J. (2014). Income Tax Compliance Costs of Working Individuals: Empirical Evidence from Germany. Public Finance Review, 42(6), 800829. doi:10.1177/1091142113488162.

Blažić, H. (2004a). Personal Income Tax Compliance Costs at an Individual Level in Croatia [CERGE-EI Working Paper]. Prague: Charles University.

Blažić, H. (2004b). Tax Compliance Costs of Small Business in Croatia [CERGE-EI Working Paper]. Prague: Charles University.

Bryden, M. (1961). The Costs of Tax Compliance [Canadian Tax Paper 25]. Toronto: Canadian Tax Foundation.

Collard, D., \& Godwin, M. R. (1999). Compliance Costs for Employers: UK PAYE and National Insurance 1995-96. Fiscal Studies, 20(4), 423-449. doi:10.1111/j.1475-5890.1999. tb00020.x.

Díaz, C., \& Delgado, M. (1995). The Compliance Costs of Personal Income Tax in Spain. In C. Sandford (Ed.), Taxation Compliance Costs Measurement and Policy (pp. 210-225). Bath: Fiscal Publications.

Evans, C. (2003). Studying the Studies: An overview of recent research into taxation operating costs. eJournal of Tax Research, 1(1).

Haig, R. M. (1935). The Cost to Business Concerns of Compliance with Tax Laws. Management Review, 24(November), 323-333. Hájek, L., Hamplová, E., Jedlička, P., \& Kovárník, J. (2013). Vybrané aspekty kauzality daňové incidence. E\&M Ekonomie a Management, 16(4),158-169.

Hasseldine, J., \& Hansford, A. (2002). The Compliance Burden of the VAT: Further Evidence from the UK. Australian Tax Forum, 17(4), 369-388.

Hruška, Z., \& Dvořáková, L. (2013). Theoretical and Practical Problems of Environmental Taxation in Conditions of the Czech Republic. E\&M Ekonomie a Management, 16(1),18-32.

Jílková, J., Pavel, J., \& Slavíková, L. (2009). Ekonomické nástroje $v$ politice životního prostředí: drahé daně a nízká účinnost. Ekonomický časopis, 57(2), 132-144.

Johnston, K. (1963). Corporations Federal Income Tax Costs: A Study of Small, Medium and Large Corporations. Columbus: Ohio State University.

Klun, M. (2001). Evaluating Efficiency and Effectiveness in the Public Sector with Special Emphasis on Tax Administration. Ljubljana: Faculty of Economics.

Klun, M. (2003). Administrative Costs of Taxation in a Transition Country: The Case of Slovenia. Finance a úvěr, 53(1-2), 75-84.

Klun, M. (2004). Compliance Costs for Personal Income Tax in a Transition Country: the Case of Slovenia. Fiscal Studies, 25(1), 93104. doi:10.1111/j.1475-5890.2004.tb00098.x.

Klun, M. (2009). Pre-filled Income Tax Returns: Reducing Compliance Costs for Personal Income Taxpayers in Slovenia. Financial Theory and Practice, 33(2), 219-233.

Klun, M., \& Blažić, H. (2005). Tax Compliance Costs for Companies in Slovenia and Croatia. Finanzarchiv, 61(3), 418-437. doi:10.1628/001522105774978967.

Malmer, H. (1995). The Swedish Tax Reform in 1990-91 and Tax Compliance Costs in Sweden. In C. Sandford (Ed.), Taxation Compliance Costs Measurement and Policy (pp. 226-262). Bath: Fiscal Publications.

Matějka, J. (2009). Soudní přezkoumání promíjení daní $v$ České republice. E\&M Ekonomie a Management, 11(1), 57-67.

Matthews, M. P. (1957). A Measurement of the Cost of Collecting Sales Tax Moneys in Selected Retail Stores. Salt Lake City: University of Utah.

Nemec, J., Pompura, L., \& Šagát. V. (2015). Administrative Costs of Taxation in Slovakia. European Financial and Accounting Journal, 10(2), 51-61. doi:10.18267/j.efaj.141. 
Orviská, M., \& Hudson, J. (2003). Tax evasion, civic duty and the law abiding citizen. European Journal of Political Economy, 19(1), 83-102. doi:10.1016/S0176-2680(02)00131-3.

Oster, C., \& Lynn, A. (1955). Compliance Costs and the Axle Mile Tax. National Tax Journal, 8(2), 209-214.

Pavel, J., \& Vítek, L. (2015). Vyvolané náklady daňového systému $v$ ČR. Politická ekonomie, 2015(3), 317-329. doi:10.18267/j. polek.1005.

Pope, J. (1993). The Compliance Costs of Taxation in Australia and Tax Simplification: The Issues. Australian Journal of Management, 18(1), 69-90.

Pudil, P., Vybíhal, V., Vítek, L., \& Pavel, J. (2004). Zdanění a efektivnost. Praha: Eurolex Bohemia.

Sandford, T. C., Godwin, M., \& Hardwick, P. (1989). Administrative and Compliance Costs of Taxation. Bath: Fiscal Publications.

Sandford, T. C. (Ed.). (1995). Tax Compliance Costs. Measurement and policy. Bath: Fiscal Publications.

Slemrod, J. R., \& Sorum, N. (1984). The Compliance Cost of the U.S. Individual Income Tax System. The National Tax Journal, 37(4), 461-474.

Smith, A. (2005). Inquiry into the Nature and Causes of the Wealth of Nations. Philadelphia: The Pensylvania State University.

Vaillancourt, F. (1987). The Compliance Cost of Taxes on Business and Individuals:
A Review of the Evidence. Public Finance, 42(3), 395-414.

Vítek, L., \& Pavel, J. (2008). Analýza nákladů soukromého sektoru vyvolaných daňovým systémem. Praha: Ministerstvo financí ČR.

Vítek, L. (2008). Ekonomická analýza zdanění príjmů. Praha: IREAS.

Vítková, J., \& Vítek, L. (2002). Spoločenské vyvolané náklady zdanění. Acta Oeconomica Pragensia, 10(1), 15-30.

Vítek, L., Pavel, J., \& Půbal, K. (2002). Efektivnost českého daňového systému. Finance a úvěr, 52(11), 669-670.

Vítek, L., Pavel, J., \& Krbová, J. (2004). Effectiveness of the Czech Tax System. Baltic Journal of Economics, 4(2), 55-71. doi:10.1080/ 1406099X.2004.10840411.

prof. Ing. Juraj Nemec, CSc. Masaryk University in Brno

Faculty of Economics and Administration Department of Public Economics juraj.nemec@econ.muni.cz

Ing. Pavol Čižmárik, Ph.D. Masaryk University in Brno Faculty of Economics and Administration cizmarik@finpal.sk

Ing. Vladimír Šagát, PhD. Bank Institute vladimir.sagat@centrum.sk 


\section{Abstract}

\section{AN ESTIMATION OF THE COMPLIANCE COSTS OF SLOVAK TAXATION Juraj Nemec, Pavol Čižmárik, Vladimír Šagát}

Most authors divide the costs of taxation into two subsets. The first subset "direct administrative costs" are the direct costs of the public sector. The second subset the "compliance costs of taxation" are the indirect expenses of the private sector connected with paying taxes. This paper focuses on the compliance costs of taxation with the goal to assess the level of compliance costs of the private sector for income taxation and compliance costs for employers connected with the administration of salaries and social contributions in Slovakia. The results, based on 2011 data show that Slovak businesses have very high costs connected with paying the taxes - compared to other developed countries and also to Slovakia's neighbours. The estimates for physical persons are particularly high, even using the most cautious assumptions. The situation deserves attention and motivates a search for some explanations and reactions. We argue that both the low level of tax compliance, because of a large shadow economy, and a too complicated tax system are the key factors determining the situation. However, neither a simplification of the tax system or real measures to cut tax evasion are on the agenda of the current left wing government. One specific factor that may have had an impact on the government's limited willingness to enact necessary radical changes, uncovered by our research, is tax illusion. The responses to our questionnaire were rather surprising $-8 \%$ of respondents felt that compliance costs were marginal and $31 \%$ felt that their level was fully acceptable. This situation provides one more - political - explanation for the current situation: if tax payers are not well informed their motivation to demand change is limited.

Key Words: Compliance costs of taxation, tax administration, Slovakia.

JEL Classification: H2O.

DOI: 10.15240/tul/001/2017-2-006 